UDC 631.527:633.1

doi: 10.54651/agri.2021.02.11

\title{
THE RESULTS OF USING IN THE BREEDING PROCESS OF COLLECTION SAMPLES OF WINTER TRITICALE IN TERMS OF GRAIN QUALITY
}

\author{
O.S. Levchenko ${ }^{1}$, O.I. Kostenko ${ }^{1}$, L.M. Holyk ${ }^{1}$, I.V. Shpakovych ${ }^{2}$ \\ ${ }^{I} N S C$ "Institute of Agriculture NAAS" \\ ${ }^{2}$ Postgraduate student of NULES
}

The aim of the work was to evaluate the collection samples of winter triticale by protein content and to establish the relationship between its quantity and other valuable economic features. Materials and methods. Collection samples of winter triticale, infrared spectrometry method, mathematical and statistical processing. Results. According to the protein content, the samples was divided into four groups. The average protein content in the collection nursery was $11.2 \%$ with the variability of individual values from $9.3 \%$ to $12.2 \%$. The average reliable inverse correlation of yield with protein content in grain $(r=-0.37)$ and weak line with starch content $(r=0.17)$ were established, Conclusions. An inverse relationship of medium strength between starch and protein content has been found. which proves the possibility of selection to increase grain yield without reducing the starch content. An inverse correlation between protein content and grain yield has been shown.

Key words: collection samples, protein, starch, valuable economic features, correlation and regression.

Protein is an important component of proper human nutrition and feeding of farm animals. That is why one of the important tasks of crop breeding is to create varieties with high protein content. The protein content in triticale grain varied from 12 to $25 \%$, depending on the genotype of the variety, agronomic measures and soil and climatic conditions of cultivation [1-3]. Triticale can provide a higher protein yield per hectare with a grain yield compared to rye. At the same time, triticale protein is more complete in amino acid composition than in wheat. In terms of macro- and microelements, triticale grain is not inferior to wheat. It contains a lot of copper, phosphorus, potassium, magnesium, calcium, sodium, zinc, manganese and iron, as well as vitamins B9, B5, B1, PP and $\mathrm{E}$ [4]. The use of triticale for baking purposes is one of the promising direction for the processing industries of the food industry. New technologies for making triticale flour allow to obtain products with a certain composition of nutrients and properties, which will be in demand in the baking, confectionery and other sectors of the food industry [5-6].

Materials and methods. Experimental studies were conducted at the NSC "Institute of Agriculture NAAS" during 2017-2019. The subject of the study were 160 collection samples of winter triticale. Analysis of the protein content in triticale grain was performed by infrared spectrometry on the device Infratec 1241.
Mathematical and statistical processing of the results of the studies was performed using the computer program Statistica 8.

Research results. The value of protein content in the collection samples of winter triticale averaged $11.2 \%$ in 2017-2019 and varied in the collection nursery from 9.3\% (Petrol variety) to $12.2 \%$ (numbers 229 and 205). According to the amount of protein in the grain, all collection samples were divided into 4 groups: high (from $12.0 \%)$, medium (11.0-11.9\%), low (10.0-10.9\%) and very low (less than $10.0 \%$ ). The most numerous were the groups with medium and low protein content, which included 21 and 13 samples, or 48.8 and $30.2 \%$ of the total collection, respectively (Fig. 1). The high-protein group consisted of 7 samples (16.3\%), and the least numerous was the group with a very low protein content, which included only 2 samples (4.7\%).

Over the years of research, significant changes in the content of protein in the grain of the collection samples of winter triticale were observed. The lowest content was determined in the best growing conditions in 2017, when the average in the collection was $10.3 \%$, and the limits of variability of individual values ranged from $8.6 \%$ in the variety Petrol to $11.7 \%$ in number 229 (Table 1). High indicators for protein content were determined in 2021 year in breeding numbers 229, 205, 207, 217, 223, 221 and variety Mundo (11.0-11.7\%), and for low content 


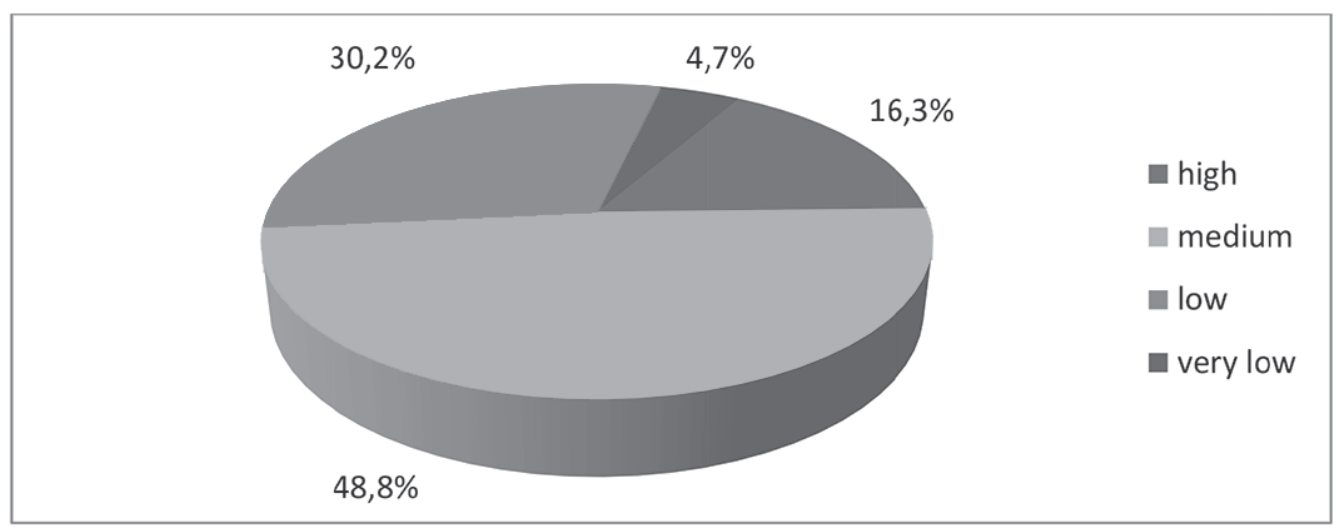

Fig. 1. Distribution of winter triticale collection samples into groups by protein content, 2017-2019

varieties Petrol and Maetok Poliskyi and numbers 191 and $87(8.6-8.9 \%)$.

In 2018, when there was a decrease in the level of yield and amount of starch in the grain compared to the previous year, the protein content increased. Its average value, in the collection samples, increased by $1.3 \%$ to $11.6 \%$.

In such samples as numbers 207, 217, 135, 205, 157 and Volemyr variety, the increase in protein content was insignificant (from 0.4 to $1.0 \%$ ), and in numbers 185 , 221,141 and others it was greater and reached $2.3 \%$. In general, the protein content of the collection samples ranged within $9.5 \%$, in the Petrol variety, to $12.6 \%$, in the number 221 . With high protein content were distinguished samples 221, Fanat, Mundo, 205, 229, that had value of this parameter from 12.4 to $12.6 \%$, and the lowest indicators were characterized by samples Petrol, Arystokrat, 123, 101, 191 (9.5-10.6\%).

According to the results of determining the amount of protein in the grain of collection samples in 2019, ambiguous results were obtained. In most samples, simultaneously with a further decrease in grain yield, an increase in protein content was found. Thus, in such numbers as 153, 215, 93 and varieties Yasha and Molfar its indicators increased by $0.5-0.7 \%$, and in the variety Solodyuk and number 53 - by 0.9 and $1.3 \%$, respectively. In samples 229, 201, 205, 207 and others, no significant increase in protein content was observed $(+0.1-0.2 \%)$. In general, compared to the previous year, in 26 samples of the collection the protein indicators increased, in $14-$ decreased, and in 3 - did not change.

It should be noted that the increase in protein in 2019 was observed mainly in grain of the collection samples, which were generally characterized by high protein content, value of which averaged from 11.0 to $12.2 \%$ over three years. Samples with low protein content
(9.9-10.9\%), such as 191, 101, 123, and others, usually had a decrease in its content by $0.1-0.7 \%$. In 2021 year, the highest protein content of all years of research was determined, which averaged $11.8 \%$ in the collection nursery, ranging from a minimum of $9.7 \%$ in the Petrol variety to a maximum of $12.8 \%$ in number 53 . In general, collection, the variety of samples by protein content was small, the value of the coefficients of variation was $1.7 \%$ in $2017 ; 1.6 \%$ in 2018 and $2.0 \%$ in 2019.

According to three-year data, the highest protein content was in numbers 229, 205, 207, 217, 223, 221 and the variety Mundo (12.0-12.2\%), which are a valuable source material for use in breeding work. Numbers 191, 101, 123 and varieties Petrol and Arystokrat, which are characterized by low protein content (up to $10.5 \%$ ).

As noted earlier, one of the main requirements for the varieties of the bakery direction of use is a high content of protein in the grain and a relatively low content of starch. Therefore, when studying the collection samples, their characteristics were analyzed and compared on these grounds. It was found that such samples with a high starch content as 101, 123, Solodiuk, Petrol, Lubomyr and Arystokrat (on average for three years - 69.0 $70.3 \%$ ) had a low protein content (9.3-10.9\%). Samples with high protein content 185, 219, 217, 205, 229, 223 (11.7-12.2\%) were characterized by low starch content (66.0-67.8\%). Similar patterns were also observed in most other collection samples, the higher the protein content in the grain, the lower the starch content and vice versa. Only two varieties Molfar and Volemyr were characterized by average parameters on both grounds: starch $-68.2 \%$, protein $-11.0 \%$, and the variety Maetok Poliskyi had low rates of both starch and protein content (66.8\% and $10,3 \%$, respectively).

Figure 2 graphically shows how the content of starch and protein in the collection samples of winter triticale 
Table 1. The protein content in the grain of the collection samples of winter triticale, $\%$

\begin{tabular}{|c|c|c|c|c|c|}
\hline \multirow{2}{*}{ Variety, breeding number } & \multicolumn{3}{|c|}{ Year of research } & \multirow{2}{*}{ Average for 3 years } & \multirow{2}{*}{ \pm for Standard } \\
\hline & 2017 & 2018 & 2019 & & \\
\hline Molfar - Standard & 9.8 & 11.3 & 12.0 & 11.0 & - \\
\hline \multicolumn{6}{|c|}{ Samples with high protein content (more than $12.0 \%$ ) } \\
\hline 229 & 11.7 & 12.4 & 12.5 & 12.2 & +1.2 \\
\hline 205 & 11.5 & 12.4 & 12.6 & 12.2 & +1.2 \\
\hline 207 & 11.6 & 12.2 & 12.4 & 12.1 & +1.1 \\
\hline 217 & 11.5 & 12.2 & 12.4 & 12.0 & +1.0 \\
\hline 223 & 11.4 & 12.2 & 12.4 & 12.0 & +1.0 \\
\hline \multicolumn{6}{|c|}{ Samples with average protein content $(11.0-11.9 \%)$} \\
\hline 185 & 10.8 & 12.3 & 12.6 & 11.9 & +0.9 \\
\hline 147 & 11.0 & 12.1 & 12.1 & 11.7 & +0.7 \\
\hline 153 & 10.6 & 11.8 & 12.3 & 11.6 & +0.6 \\
\hline 53 & 10.3 & 11.5 & 12.8 & 11.5 & +0.5 \\
\hline Yasha & 10.6 & 11.5 & 12.2 & 11.4 & +0.4 \\
\hline Kotyhoroshko & 10.1 & 11.8 & 11.9 & 11.3 & +0.3 \\
\hline 201 & 10.1 & 11.7 & 11.8 & 11.2 & +0.2 \\
\hline Volemyr & 10.7 & 11.1 & 11.3 & 11.0 & 0.0 \\
\hline \multicolumn{6}{|c|}{ Samples with low protein content $(10.0-10.9 \%)$} \\
\hline 149 & 9.6 & 11.9 & 11.3 & 10.9 & -0.1 \\
\hline Lubomyr & 10.2 & 11.0 & 10.9 & 10.7 & -0.3 \\
\hline 181 & 9.5 & 11.1 & 11.3 & 10.6 & -0.4 \\
\hline 87 & 8.8 & 11.3 & 11.0 & 10.5 & -0.5 \\
\hline 203 & 9.1 & 10.9 & 11.1 & 10.4 & -0.6 \\
\hline Maetok Poliskyi & 8.9 & 11.1 & 10.8 & 10.3 & -0.7 \\
\hline 123 & 9.6 & 10.3 & 10.2 & 10.0 & -1.0 \\
\hline \multicolumn{6}{|c|}{ Samples with very low protein content (less than $10.0 \%$ ) } \\
\hline 191 & 8.7 & 10.6 & 10.4 & 9.9 & -1.1 \\
\hline Petrol & 8.6 & 9.5 & 9.7 & 9.3 & -1.7 \\
\hline Average in the collection & 10.3 & 11.6 & 11.8 & 11.2 & \multirow{4}{*}{-} \\
\hline Lim in the collection & $8.6-11.7$ & $9.5-12.6$ & $9.7-12.8$ & $9.3-12.2$ & \\
\hline S & 1.1 & 1.1 & 1.3 & 1.1 & \\
\hline $\mathrm{V}, \%$ & 1.7 & 1.6 & 2.0 & 1.7 & \\
\hline
\end{tabular}

changed over the years of research. There is an obvious tendency to reduce the protein content in the years when there was an increase in starch content and vice versa. The patterns of changes in the starch content were more stable and characteristic of all samples of the collection over the years of research. However, the protein content in 2019, which has already been discussed above, observed deviations from these patterns. Thus, in 14 samples of the collection the protein content even slightly decreased, and in 3 samples it did not change, although this year the lowest yield and starch content were recorded.
To establish the patterns of formation of valuable economic characteristics, the correlations between the amount of protein and other indicators of the lines of competitive varietal testing of triticale in the winter baking direction were calculated.

The study of correlations between the main characteristics that determine the yield and quality of products in crops, allows us to identify which elements can further improve their performance, and use these patterns in breeding work on the stage of evaluating new material. In order to establish the strength and direction of the links between such important features as grain yield and starch and protein content, the method of correlation 


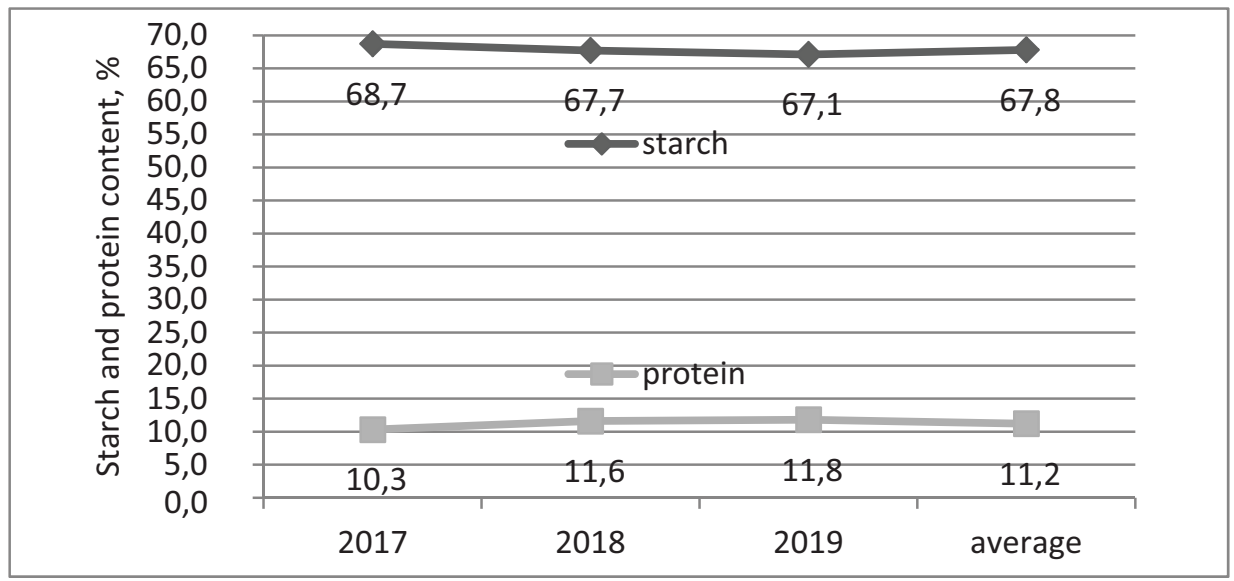

Fig. 2. The content of protein and starch in the grain on average in the collection nursery of winter triticale by years of research, 2017-2019

Table 2. Correlation between the main features of suitability for baking in the collection samples of winter triticale, 2017-2019

\begin{tabular}{|c|c|c|}
\hline \multirow{2}{*}{ Features } & \multicolumn{2}{|c|}{$\begin{array}{c}\text { The value of the correlation } \\
\text { coefficient (r) }\end{array}$} \\
\cline { 2 - 3 } & Yield & Starch contain \\
\hline Starch contain & $0.17 *$ & - \\
\hline Protein contain & $-0.37 * *$ & $-0.64 * *$ \\
\hline
\end{tabular}

Note. * unreliable; $* *$ reliable at $\mathrm{P}_{0.05}$

analysis was used [7-8]. Correlation coefficients were calculated from the average three-year indicators of these traits. According to the results of the analysis, a weak direct correlation of yield with starch content $(\mathrm{r}=0.17)$ and medium inverse correlation with protein content $(r=-0.37)$ were established, which proves the possibility of breeding to increase grain yield without reducing starch content (Table 2). An inverse relationship of medium strength $(\mathrm{r}=-0.64)$ was found between the starch and protein content, which is confirmed by the actually obtained indicators of these characteristics. Correlations between yield and protein content and between protein and starch content are significant at the 5\% level of significance $\left(\mathrm{P}_{0.05}\right)$, and the relationship between yield and starch content was unreliable due to insufficient to prove the significance of weak links number of observation pairs.

In order to establish quantitative changes in the indicators of one trait depending on the changes in another, with which the correlation was determined, the method of regression analysis was used. In this case, the pairwise correlation between the corresponding features is displayed graphically as a regression line. To construct a regression line and a so-called scatter plot, or correlation

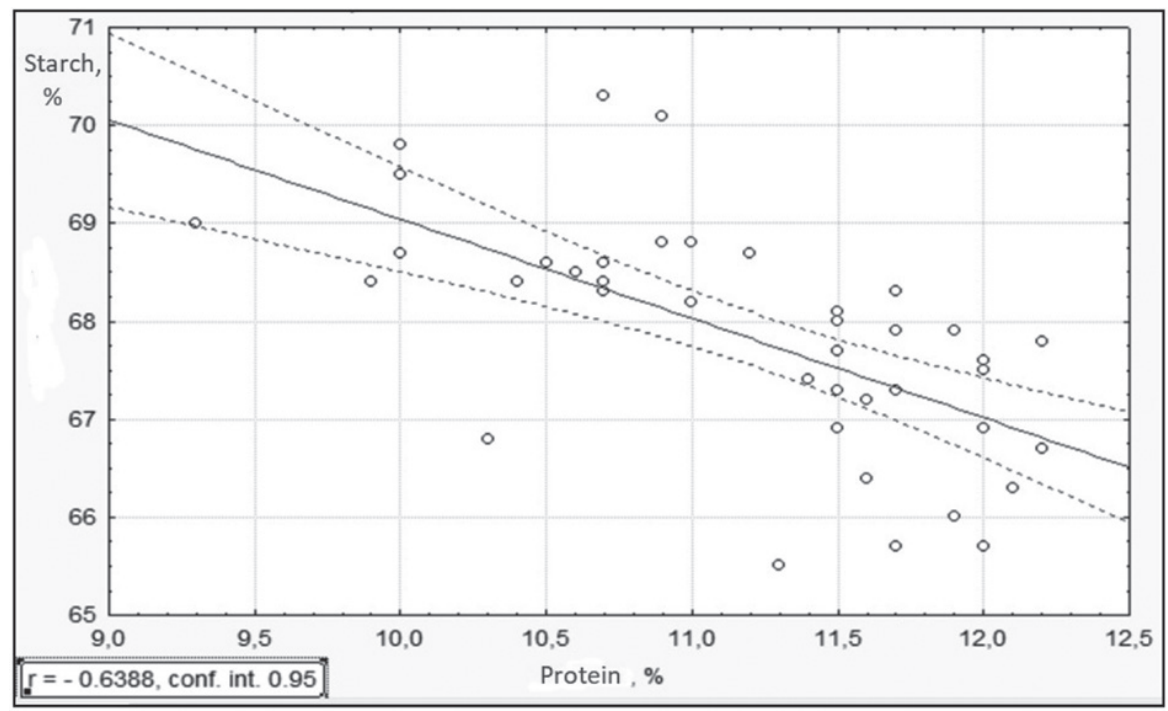

Fig. 3. Point graph and theoretical regression line between protein and starch content in grain of winter triticale collection samples, 2017-2019 


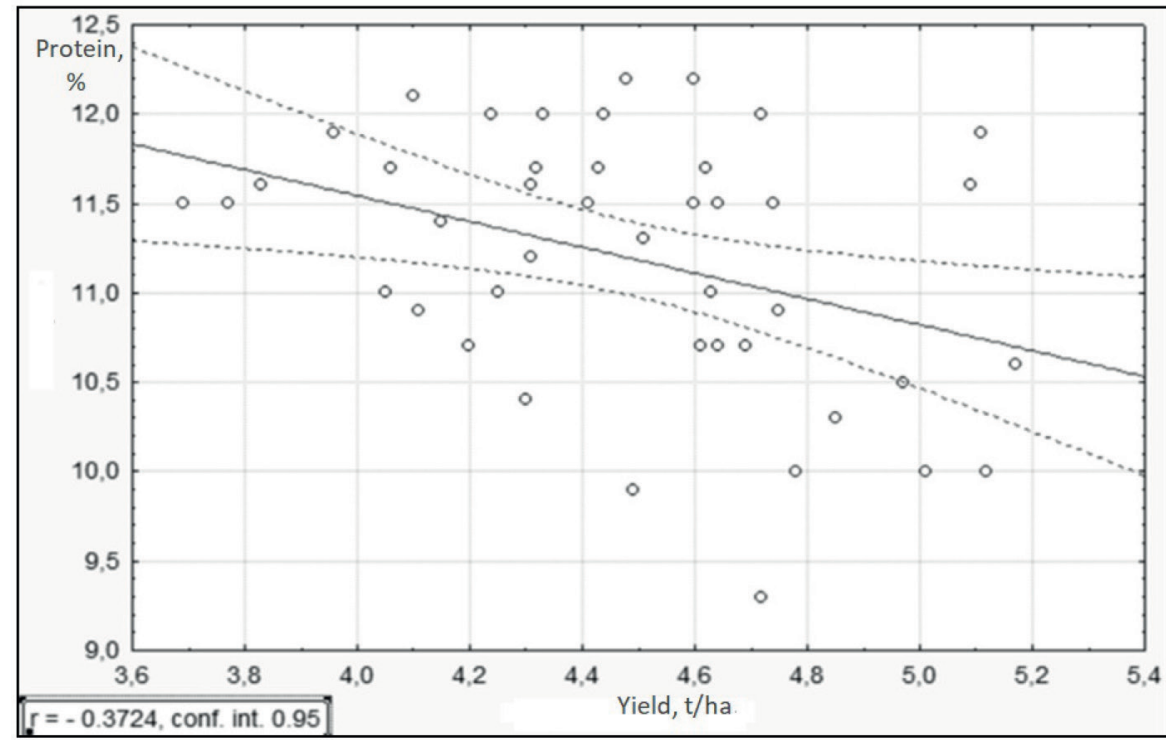

Fig. 4. Point graph and theoretical regression line between yield and protein content in the grain of winter triticale collection samples, 2017-2019

field, the values of the parameters of two interrelated features are plotted on different coordinate axes. The scatter plot indicates the scatter of individual observations and allows to build a theoretical regression line based on them.

The theoretical regression line clearly confirms the inverse correlation between the characteristics of protein and starch content in the grain of winter triticale collection samples and indicates how much the starch content may decrease with increasing content of protein (Fig. 3). It is calculated that when the value of protein content in the grain is $9.0 \%$, the starch content is $70.1 \%$, and when the protein content increases to $12.5 \%$, the starch content decreases to $66.5 \%$. With an increase in protein content by $1.0 \%$, the starch content may also decrease by $1.0 \%$ and vice versa.

Figure 4 graphically shows the results of inverse correlation between protein content and grain yield as a regression line. The theoretical regression line indicates that with an increase in yield by $3.6-5.4 \mathrm{t} /$ ha may decrease the protein content by $11.8-10.6 \%$ or $5.2 \%$. With increasing yields per 1 ton, the protein content may decrease by $0.8 \%$.

\section{Conclusions}

1. It was found that the protein content on average in the collection nursery was $11.2 \%$ with the variability of individual values from 9.3\% (Petrol variety) to $12.2 \%$ (numbers 229 and 205). It was determined that the lowest protein content in the samples (average 10.3\%) was observed in the best growing conditions and the most productive 2017 .

2. The established average significant inverse correlation of yield with protein content in grain $(\mathrm{r}=-0.37)$ and weak line with starch content $(\mathrm{r}=0.17)$, which proves the possibility of selection to increase grain yield without reducing the content starch. An inverse relationship of medium strength $(\mathrm{r}=-0.64)$ between starch and protein content was found.

3. The inverse correlation between protein content and grain yield is proved. It is determined that the theoretical regression line indicates that with an increase in yield from 3.6 to $5.4 \mathrm{t} /$ ha may decrease the protein content by $11.8-10.6 \%$ or by $5.2 \%$. With increasing yields per 1 ton, the protein content may decrease by $0.8 \%$.

\section{REFERENCES}

1. Sukhova O. V. (2013). Issledovanie khimicheskogo sostava zerna tritikale kak osnovnogo belkovosoderzhashchego syr'ya [Investigation of the chemical composition of triticale grain as the main protein-containing raw material]. Bulletin of NGIEI, 8 (27), 22-31 [in Russian].

2. Ponomarev S. N., Ponomareva M. L., Mannapova G. S., Ilalova L. V. (2021). Urozhajnost' i soderzhanie belka v zerne kollekcionnykh obrazcov ozimoj tritikale. [Productivity and protein content in grain of collection samples of winter triticale]. Agricultural science of the Euro-North-East, 4, 30-34 [in Russian]. 
3. Kyrychenko V. V., Petrenkova V. P., Kobyzieva L. N., Shchypak H. V. (2016). Selektsiia heksaploidnykh trytykale na pidvyshchennia adaptyvnykh vlastyvostei, urozhainosti ta yakosti zerna [Selection of hexaploid triticale for the adjustment of adaptive power, productivity and quality of grain]. P. 313-373 [in Ukrainian].

4. Henning J., Sune T. T., Jan K.S. (2020). The potential for biorefining of triticale to protein and sugar depends on nitrogen supply and harvest time. Industrial Crops and Products, 149, 41-54 [in English].

5. Karchevskaya O.V., Dremucheva G.F., Grabovec A.I. (2019). Nauchnye osnovy i tekhnologicheskie aspekty primeneniya zerna tritikale $\mathrm{v}$ proizvodstve khlebobulochnykh izdelij [Scientific foundations and technological aspects of the use of triticale grain in the production of bakery products]. Bread cookies of Russia, 5, 28-29 [in Russian].
6. Shchypak H.V. (2019). Trytykale i pshenytsia: selektsiia na adaptyvnist, urozhainist, yakist [Triticale and wheat: selection for adaptability, yiel]. K.: Atopol P. 480 [in Ukrainian].

7. Levchenko O.S. (2018). Vmist krokhmaliu v zerni trytykale ozymoho ta yoho vzaiemozviazok z inshymy hospodarskoho-tsinnymy oznakamy. Aktualni problemy ta innovatsii $\mathrm{v}$ suchasnomu zemlerobstvi [Instead of starch in the grain of triticale of winter, that yogo interconnection with the same stately-valuable signs]. Materials of the scientific-practical conference of young students and specialties. Kyiv. P. 18-19 [in Ukrainian].

8. Hirko V.S., Sabadin N.A. (2007). Trytykale ozyme. Biolohiia. Selektsiia. Nasinnytstvo [Triticale for winter. Biology. Selection. Nasinnystvo]. Kyiv: Agrarian science. P. 523-659 [in Ukrainian].

\section{LITERATURE}

1. Сухова О. В. Исследование химического состава зерна тритикале как основного белковосодержащего сырья. Вестник НГИЭИ. 2013. №8 (27). C. 22-31.

2. Пономарев С. Н., Пономарева М. Л., Маннапова Г. С., Илалова Л. В. Урожайность и содержание белка в зерне коллекционных образцов озимой тритикале. Аграрная наука Евро-Северо-Востока. 2021. №4. С. 30-34.

3. Кириченко В. В., Петренкова В. П., Кобизєва Л. Н., Щипак Г. В. Селекція гексаплоїдних тритикале на підвищення адаптивних властивостей, урожайності та якості зерна. У кн.: Основи управління продукційним процесом польових культур монографія, Харків, ФЩП Бровін О. В. 2016. C. 313-373.

4. Henning J., Sune T. T., Jan K.S. The potential for biorefining of triticale to protein and sugar depends on nitrogen supply and harvest time. Industrial Crops and Products. 2020. Volume 149. C. 41-54.

5. Карчевская О.В., Дремучева Г.Ф., Грабовец А.И. Научные основы и технологические аспекты применения зерна тритикале в производстве хлебобулочных изделий. Хлебопеченье России. 2016. №5. С. 28-29.

6. Щипак Г.В. Тритикале і пшениця: селекція на адаптивність, урожайність, якість. К.:Атопол, 2019. $480 \mathrm{c.}$

7. Левченко О.С. Вміст крохмалю в зерні тритикале озимого та його взаємозв'язок з іншими господарського-цінними ознаками. Актуальні проблеми та інновації в сучасному землеробстві (до 100-річчя Національної академії аграрних наук України): матеріали науково-практичної конференції молодих учених і спеціалістів (Чабани, 20 22 листопада 2018p.). Київ, 2018. С. 18-19.

8. Гірко В.С., Сабадін Н.А. Тритикале озиме. Біологія. Селекція. Насінництво. Технологія вирощування. Селекція, насінництво і технології вирощування зернових колосових культур у Лісостепу України / за ред. В.Т. Колючого, В.А. Власенка, Г.Ю. Борсука. Київ:Аграрна наука, 2007. C. 523-659.

\section{О.С. Левченко ${ }^{1}$, О.І. Костенко ${ }^{1}$, Л.М. Голик ${ }^{1}$, І.В. Шпакович ${ }^{2}$ \\ Результати використання у селекційному процесі колекційних зразків тритикале озимого за показниками якості зерна}

Метою роботи була оцінка колекиійних зразків тритикале озимого за вмістом білка та встановлення залежності між його кількістю та іншими цінними господарськими показниками. Під час дослідження використовували метод інфрачервоної спектрометрії та математико-статистичну обробку. За результатами дослідження було проведено розподіл колекиійних зразків на 4 групи: із високим вмістом (від 12,0\%), середнім (11,0-11,9\%), низьким (10,0-10,9\%) та дуже низьким (менше 10,0\%) і встановлено, 
що високобілкова група складалась із 7 зразків (16,3\%). Найменш чисельною була група із дуже низьким вмістом білка, в яку ввійшло лише 2 зразки (4,7\%). Внаслідок досліджень вміст протеїну, за середнім показником, у колекиійному розсаднику становив 11,2\% із межсами мінливості індивідуальних значень від 9,3\% (сорт Петрол) до 12,2\% (номери 229 і 205). Найнижчий вміст білка у зразків (в середньому 10,3\%) визначено в кращому за умовами виромування і найбільш врожайному 2017 р. Виявлено обернений зв'язок середньої сили $(r=-0,64)$ між вмістом крохмалю $і$ білка. Встановлена середня достовірна обернена кореляиія врожайності із вмістом у зерні білка $(r=-0,37)$ та слабка пряма із вмістом крохмалю $(r=0,17)$, що доводить можливість проведення селекиії на підвищення врожайності зерна, не знижуючи при цьому вміст крохмалю. Доведено обернений корелящійний зв'язок між вмістом білка і врожайністю зерна.

Ключові слова: колекиійні зразки, білок, крохмаль, цінні господарські ознаки, кореляція і регресія.

\section{ВІдОМОСТІ ПІРО АВТОРІв}

Levchenko O.S., Doctor of Philosophy, NSC "Institute of Agriculture NAAS”, e-mail: feniks1213@gmail.com, ph. 0959070254, ORCID ID: 0000-0003-1639-326X

Kostenko O.I., Candidate of agriculture science, NSC "Institute of Agriculture NAAS", e-mail: lekost@ukr.net, ORCID ID: 000-0003-3048-1995
Holyk L.M., Candidate of agriculture science, senior scientist, NSC "Institute of Agriculture NAAS", e-mail: holykselekcioner@gmail.com, ph. 0672701209, ORCID ID: 0000-0002-7157-6520

Shpakovych I.V., postgraduate student of NULES, e-mail: irunashpakovich@gmail.com, ph. 09853339001
Левченко О.С., доктор філософії, ННЦ «Інститут землеробства НАAН», e-mail: feniks1213@gmail.com, тел. 0959070254, ORCID ID: 0000-0003-1639-326X

Костенко О.І., канд. с.-Г. Н., ННЦ «Інститут землеробства HAAH», e-mail: lekost@ukr.net, ORCID ID: 000-00033048-1995
Голик Л.М., канд. с.-г. н., ст. н. сп., ННЦ «Інститут землеробства НАAН», e-mail: holykselekcioner@gmail. com, тел. 0672701209, ORCID ID: 0000-0002-7157-6520

Шпакович І.В., аспірант НУБіП, е-mail: irunashpakovich@gmail.com, тел. 09853339001

Надійшла 6.10.2021 